\title{
The protective activity of immunostimulants against Listeria monocytogenes infection in mice
}

\author{
H. TOMIOKA, K. SATO and H. SAITO* \\ Department of Microbiology and Immunology, Shimane Medical University, Izumo 693, Japan
}

\begin{abstract}
Summary. The function of peritoneal macrophages induced by intraperitoneal (i.p.) injection of attenuated Streptococcus pyogenes (OK-432), Bacillus Calmette Guérin (BCG), proteinbound polysaccharide preparation isolated from Coriolus vesicolor (PSK) or Lactobacillus casei was examined. The PMA-triggered respiratory burst (production of $\mathrm{O}_{2}{ }^{-}$and $\mathrm{H}_{2} \mathrm{O}_{2}$ ) of macrophages induced by OK-432, BCG or Lac. casei was greater than that of resident or thioglycollate-stimulated macrophages and was similar to that of BCG-activated macrophages. PSK failed to enhance the production of $\mathrm{O}_{2}{ }^{-}$or $\mathrm{H}_{2} \mathrm{O}_{2}$ by macrophages. Alkaline phosphodiesterase (APD) activity was reduced in macrophages induced by OK-432, BCG or Lac. case injection and in BCG-activated macrophages. The APD activity of macrophages obtained 7 and 13 days after i.p. injection of PSK was elevated, as with thioglycollatestimulated macrophages. Listericidal activity in vitro was enhanced in macrophages obtained in 13 and 7 days, but suppressed in macrophages obtained 2 days after OK-432, BCG or Lac. casei injection. Lac. casei administered either 2 or 13 days before infection with Listeria monocytogenes was protective but $\mathrm{OK}-432$, BCG $(0 \cdot 1 \mathrm{mg})$ and PSK were not, even though they were able to stimulate macrophage function.
\end{abstract}

\section{Introduction}

Attenuated Streptococcus pyogenes $\mathrm{Su}$ (OK-432), Bacillus Calmette Guérin (BCG), and a protein-bound polysaccharide preparation isolated from Coriolus vesicolor (PSK) have immunopotentiating properties such as enhancing host resistance to microbial infections or malignant tumours. ${ }^{1-5}$ Lactobacillus case $i$ also enhances resistance to bacterial and viral infections ${ }^{6-8}$ and malignant tumours. ${ }^{9}$ We have reported previously that the anti-Listeria monocytogenes activity of Lac. case $i$ in mice is most evident 2 and 13 days after administration, and resistance is associated with stimulation of macrophage functions and an increase in the number of macrophages. ${ }^{7.10}$ In the present study, the protective action of OK-432, BCG and PSK against $L$. monocytogenes infection in mice was compared to that of Lac. casei.

\section{Materials and methods}

\section{Animals}

Female 5-week-old ddY mice, purchased from the Japan SLC Inc., Shizuoka, Japan, were used.

\section{Immunostimulants}

BCG was obtained from Japan BCG Pharmaceutical Co., Tokyo, Japan. OK-432 and PSK were generous gifts from Chugai Pharmaceutical Co., Tokyo and Kureha Chemical Ind. Co., Tokyo, respectively. Lac. casei YIT 0003 was cultivated in Rogosa liquid medium ${ }^{11}$ at $37^{\circ} \mathrm{C}$ for $18 \mathrm{~h}$, washed and suspended in saline, and injected intraperitoneally (i.p.) or intravenously (i.v.) into mice at the appropriate dilution.

\section{Bacteria}

L. monocytogenes strain EGD was grown in Tryptic Soy Broth (Difco) at $37^{\circ} \mathrm{C}$ for $18 \mathrm{~h}$, washed with saline, suspended in phosphate buffered saline (PBS, pH 7.2) containing glycerol $10 \%$, and stored at $-80^{\circ} \mathrm{C}$. The bacterial suspensions were thawed and diluted in saline immediately before use.

\section{Macrophage monolayers}

Peritoneal exudate cells were obtained from mice at the appropriate time after i.p. injection of the various immunostimulants. Cells were harvested from five mice with phenol red-free Hanks's Balanced Salts Solution (HBSS, pH 7.2), pooled, centrifuged, and suspended in phenol red-free HBSS. For macrophage culture, the cells were suspended in Eagle's Minimal 
Essential Medium (MEM; Nissui Pharmaceutical Co., Tokyo) supplemented with glucose $0.4 \%, 1 \mathrm{~mm}$ pyruvate, 0.01 volumes of non-essential amino acids (Difco), and fetal bovine serum (M.A. Bioproducts, MD, USA) $10 \%$, and poured into 35 - or $50-\mathrm{mm}$ plastic culture dishes (Nunc, Roskilde, Denmark) or on to plastic sheets (14 mm; Wako Pure Chemical, Osaka, Japan) in glass culture dishes ( $45 \mathrm{~mm})$. After incubation at $37^{\circ} \mathrm{C}$ for $4-6 \mathrm{~h}$ in an atmosphere of $\mathrm{CO}_{2} 5 \%$ in humidified air, the cultures were rinsed with PBS to remove non-adherent cells. Macrophages obtained 24 days after i.p. injection of $1 \mathrm{mg}$ of $\mathrm{BCG}$ and 4 days after i.p. injection of $2 \mathrm{ml}$ of thioglycollate served as activated and stimulated macrophages, respectively.

\section{Assay for superoxide $\left(\mathrm{O}_{2}{ }^{-}\right)$release}

$\mathrm{O}_{2}{ }^{-}$release was assayed according to the method of Johnston et al. ${ }^{12}$ with slight modifications. Macrophage monolayers, derived from $4 \times 10^{6}$ peritoneal exudate cells, were overlaid with $2.5 \mathrm{ml}$ of HBSS (containing glucose $0.1 \%$, without phenol red) and $200 \mu \mathrm{mol}$ of cytochrome C (Sigma). A 10- $\mu$ l volume of phorbol myristate acetate (PMA; Sigma) was added to the incubation mixture to give a final concentration of $10 \mathrm{ng} / \mathrm{ml}$. The cultures were placed in a $\mathrm{CO}_{2}$ incubator for $60 \mathrm{~min}$. After incubation, the medium was removed and the reduction of cytochrome $\mathrm{C}$ was measured spectrophotometrically at $550 \mathrm{~nm}$.

\section{Assay for $\mathrm{H}_{2} \mathrm{O}_{2}$ release}

Macrophage monolayers derived from $2 \times 10^{6}$ peritoneal exudate cells were overlaid with $2.5 \mathrm{ml}$ of HBSS (containing $0.1 \%$ glucose, without phenol red) and horseradish peroxidase (type II; Sigma) $50 \mu \mathrm{g} / \mathrm{ml}$ was added. A $10-\mu 1$ volume of PMA and $25 \mu$ l of scopoletin (reduced type; Sigma) were added to the incubation mixture to give final concentrations of $10 \mathrm{ng} / \mathrm{ml}$ and $5 \mathrm{nmol} / \mathrm{ml}$, respectively. The dishes were placed in a $\mathrm{CO}_{2}$ incubator for 10-15 min. After incubation, the medium was removed, and the oxidation of scopoletin by $\mathrm{H}_{2} \mathrm{O}_{2}$ was measured by fluorescence (excitation at $350 \mathrm{~nm}$, emission at $460 \mathrm{~nm})^{13}$

\section{Assay for alkaline phosphodiesterase ( $A P D)$ activity}

Cells from macrophage monolayers, prepared in 50mm plastic culture dishes by seeding (3-4) $\times 10^{6}$ cells, were harvested into Triton X-100 $0 \cdot 1 \%$. Cell lysates were stored at $-80^{\circ} \mathrm{C}$ until assayed APD activity was measured by the method of Edelson and Erbs. ${ }^{14}$

\section{Macrophage microbicidal activity}

Macrophage monolayers were prepared on plastic sheets in glass culture dishes by seeding $9 \times 10^{6}$ cells. The monolayer was overlaid with MEM containing $L$. monocytogenes $\left(10^{6}\right.$ bacteria/ml $)$, incubated at $37^{\circ} \mathrm{C}$ for $1 \mathrm{~h}$, washed with PBS to remove the nonphagocytosed bacteria, and fresh MEM containing penicillin $\mathrm{G} 0.2 \mu \mathrm{g} / \mathrm{ml}$ was added to inhibit growth of extracellular organisms. The infected cells were incubated at $37^{\circ} \mathrm{C}$ for $10 \mathrm{~h}$ in a $\mathrm{CO}_{2}$ incubator, washed with PBS, and lysed with distilled water. The number of viable, intracellular bacteria was counted by plating serial 10-fold dilutions of cell lysate on Trypto Soy Agar (Eiken Chemical Co., Tokyo). In some cases, the sheet was fixed with methanol and stained with Giemsa solution, and the number of macrophages was counted by microscopy.

\section{Mouse protection test}

Mice were given $0 \cdot 1 \mathrm{mg}$ of Lac. casei, OK-432, BCG or PSK by i.v. injection 2, 7 or 13 days before i.v. infection with $L$. monocytogenes $10^{6}$ cells. Mice given $1 \mathrm{mg}$ of BCG by i.v. injection 24 days before infection were also used. The survival of mice was recorded 7 days after infection. Alternatively, animals were killed $6 \mathrm{~h}$ or $48 \mathrm{~h}$ after infection with L. monocytogenes $10^{4}$ cells, and the number of viable $L$. monocytogenes in the liver was determined as previously described. ${ }^{7}$

\section{Statistical analysis}

Student's $t$ and $\chi^{2}$ tests were used to determine statistical significance.

\section{Results}

\section{The respiratory burst of macrophages}

The PMA-triggered respiratory burst (production of $\mathrm{O}_{2}{ }^{-}$and $\mathrm{H}_{2} \mathrm{O}_{2}$ ) of macrophages induced with various immunostimulants was measured (table I). The $\mathrm{O}_{2}{ }^{-}$and $\mathrm{H}_{2} \mathrm{O}_{2}$ production of macrophages harvested 2, 7 and 13 days after i.p. injection of Lac. casei was greater than that of resident or thioglycollatestimulated macrophages. Production by Lac. caseiinduced macrophages on days 13 and 7 was similar to that of BCG-activated macrophages, whereas macrophages on day 2 produced lower levels of $\mathrm{O}_{2}{ }^{-}$and $\mathrm{H}_{2} \mathrm{O}_{2}$ than BCG-activated macrophages. The PMAtriggered respiratory burst of $\mathrm{OK}-432$ and $\mathrm{BCG}$ $(0.1 \mathrm{mg})$-induced macrophages was greater than that of resident or thioglycollate-stimulated macrophages and similar to that of BCG-activated macrophages and Lac. case $i$-induced macrophages at day 7 or 13, whereas production by PSK-induced macrophages was similar to that of resident macrophages. The increase in respiratory burst of macrophages induced by $\mathrm{OK}-432, \mathrm{BCG}$ or PSK 2 days before cell harvest was intermediate between that of thioglycollatestimulated macrophages and BCG-activated macrophages. 
Table I. The effect of immunostimulants on the respiratory burst and enzyme activity of peritoneal macrophages

\begin{tabular}{|c|c|c|c|c|c|c|c|c|}
\hline \multicolumn{3}{|c|}{$\begin{array}{l}\text { Immunostimulant } \\
\text { administration }\end{array}$} & \multicolumn{4}{|c|}{$\begin{array}{l}\text { PMA-stimulated } \\
\text { production of }\end{array}$} & \multirow{2}{*}{\multicolumn{2}{|c|}{$\begin{array}{c}\text { APD } \\
\text { activity } \\
\text { (nmol/min/ } / \\
\mathrm{mg} \text { ) }\end{array}$}} \\
\hline Agent & Dose & Day* & \multicolumn{4}{|c|}{$\left(\mathrm{pmol} / \mathrm{min} / 10^{6} \mathrm{cells}\right)$} & & \\
\hline None & $\ldots$ & $\ldots$ & 110 & (18) & 180 & (10) & 13.4 & $(0 \cdot 6)$ \\
\hline Thioglycollate & $2 \mathrm{ml}$ & 4 & 140 & (16) & 250 & $(25) \dagger$ & $18 \cdot 6$ & $(1 \cdot 0) \dagger$ \\
\hline BCG & $1 \mathrm{mg}$ & 24 & 720 & $(25) \ddagger$ & 2000 & $(110)^{\ddagger}$ & $2 \cdot 2$ & $(0 \cdot 3) \ddagger$ \\
\hline Lac. casei & $0 \cdot 1 \mathrm{mg}$ & 13 & 730 & $(38) \ddagger$ & 2000 & (9) $\ddagger$ & $2 \cdot 3$ & $(0 \cdot 2) \ddagger$ \\
\hline & & $\begin{array}{l}7 \\
2\end{array}$ & $\begin{array}{l}710 \\
520\end{array}$ & $\begin{array}{l}(11) \ddagger \\
(34) \ddagger\end{array}$ & $\begin{array}{l}1900 \\
1400\end{array}$ & $\begin{array}{l}(44) \ddagger \\
(39) \ddagger\end{array}$ & $\begin{array}{l}3 \cdot 6 \\
4 \cdot 1\end{array}$ & $\begin{array}{l}(1 \cdot 0) \ddagger \\
(0.9) \ddagger\end{array}$ \\
\hline OK -432 & $0.1 \mathrm{mg}$ & $\begin{array}{r}13 \\
7 \\
2\end{array}$ & $\begin{array}{l}540 \\
720 \\
330\end{array}$ & $\begin{array}{l}(30) \ddagger \\
(10) \ddagger \\
(24) \ddagger)\end{array}$ & $\begin{array}{l}1700 \\
1700 \\
1000\end{array}$ & $\begin{array}{l}(77) \ddagger \\
(120) \ddagger \\
(25) \ddagger\end{array}$ & $\begin{array}{l}4 \cdot 4 \\
2 \cdot 4 \\
4 \cdot 1\end{array}$ & $\begin{array}{l}(0 \cdot 2) \ddagger \\
(0 \cdot 1) \ddagger \\
(0 \cdot 8) \ddagger\end{array}$ \\
\hline BCG & $0 \cdot 1 \mathrm{mg}$ & $\begin{array}{r}13 \\
7 \\
2\end{array}$ & $\begin{array}{l}640 \\
570 \\
280\end{array}$ & $\begin{array}{l}(17) \ddagger \\
(20) \ddagger \\
(16) \ddagger\end{array}$ & $\begin{array}{r}1900 \\
1700 \\
400\end{array}$ & $\begin{array}{l}(87) \ddagger \\
(200) \ddagger \\
(15) \ddagger\end{array}$ & $\begin{array}{l}5 \cdot 0 \\
4 \cdot 2 \\
5 \cdot 3\end{array}$ & $\begin{array}{l}(0 \cdot 2) \ddagger \\
(0 \cdot 2) \ddagger \\
(0 \cdot 1) \ddagger\end{array}$ \\
\hline PSK & $0.1 \mathrm{mg}$ & $\begin{array}{r}13 \\
7 \\
2\end{array}$ & $\begin{array}{l}110 \\
100 \\
300\end{array}$ & $\begin{array}{l}\text { (3) } \\
\text { (3) } \\
\text { (9) } \ddagger\end{array}$ & $\begin{array}{l}160 \\
150 \\
480\end{array}$ & $\begin{array}{c}(20) \\
(9) \\
(12) \ddagger\end{array}$ & $\begin{array}{r}16 \cdot 1 \\
18 \cdot 2 \\
6 \cdot 8\end{array}$ & $\begin{array}{l}(0 \cdot 4) \ddagger \\
(0 \cdot 4) \ddagger \\
(0 \cdot 1) \ddagger\end{array}$ \\
\hline
\end{tabular}

Results are presented as the mean (SEM) of three determinations.

* The number of days before macrophage harvest that the agents were administered to the mice.

$\dagger$ Significantly different from resident macrophages, $\mathrm{p}<0.05$.

$\ddagger$ Significantly different from resident macrophages, $\mathrm{p}<0 \cdot 01$.

\section{Enzyme activity in macrophage lysates}

As shown in table I, APD activity, which is known to increase in stimulated macrophages and to decrease in activated macrophages, ${ }^{15}$ was significantly elevated in thioglycollate-stimulated macrophages, but was markedly depressed in BCG-activated macrophages. The APD activity of OK-432-, BCG-, and Lac. caseiinduced macrophages harvested 2, 7 or 13 days after i.p. injection and PSK-induced macrophages harvested 2 days after injection was depressed; the activity of macrophages obtained 7 or 13 days after i.p. injection of PSK was elevated.

\section{In-vitro listericidal activity of macrophages}

As shown in table II, the in-vitro listericidal activity of thioglycollate-stimulated and BCG-activated macrophages was enhanced compared to that of resident macrophages. The activity of OK-432- or BCGinduced macrophages was similar to that of Lac. caseiinduced macrophages. The listericidal activity of PSK-induced macrophages was enhanced on day 13, but not on day 7 or 2 compared to that of resident or thioglycollate-stimulated macrophages.

\section{Protective activity of immunostimulants against $L$. monocytogenes infection}

Mice treated i.v. with the various immunostimulants were infected with $L$. monocytogenes $10^{6}$ cells, and survival was determined 3 and 7 days after infection (table III). Prolongation of survival was significant in Lac. casei-treated mice, but not in mice pre-treated with OK-432, BCG $(0 \cdot 1 \mathrm{mg})$ or PSK. The increase in survival time in mice treated with $1 \mathrm{mg}$ of BCG 24 days before infection was greater than that of $L a c$. casei-treated mice.

\section{Inhibition of L. monocytogenes multiplication in vivo}

Killing of L. monocytogenes in the liver during the first $6 \mathrm{~h}$ after infection was significantly enhanced by administration of Lac. case $i$, but not by administration of the other agents, when given 13 or 7 days before infection (table III). The early killing of organisms was greatest in mice given $1 \mathrm{mg}$ of BCG 24 days before infection. The multiplication of the organisms between 6 and $48 \mathrm{~h}$ after infection was significantly suppressed by pre-treatment with all of the agents given 13, 7 or 2 days before infection. Inhibition of growth of the organisms during the middle phase was greatest in mice given $1 \mathrm{mg}$ of BCG 24 days before infection. Inhibition of growth of L. monocytogenes was not seen in mice given PSK 13 or 7 days before infection.

\section{Discussion}

In this study we have used immunostimulants injected i.p. and i.v. to investigate the regulation of 
Table II. The effect of immunostimulants on the listericidal activity of peritoneal macrophages in vitro

\begin{tabular}{llr|rl}
\hline \multicolumn{1}{c|}{ Immunostimulant administration } & $\begin{array}{r}\text { Listericidal activity- } \\
\text { Agent }\end{array}$ & Dose & Day* & $\begin{array}{r}\text { rean (SEM) percentage } \\
\text { survival after 10 h }\end{array}$ \\
\hline None & $\ldots$ & $\ldots$ & 136 & $(6)$ \\
Thioglycollate & $2 \mathrm{ml}$ & 4 & 112 & $(6)$ \\
BCG & $1 \mathrm{mg}$ & 24 & 38 & $(3) \dagger$ \\
Lac. casei & $0 \cdot 1 \mathrm{mg}$ & 13 & 15 & $(1) \dagger$ \\
& & 7 & 41 & $(3) \dagger$ \\
& & 2 & 470 & $(49) \ddagger$ \\
OK-432 & $0 \cdot 1 \mathrm{mg}$ & 13 & 51 & $(15) \dagger$ \\
& & 7 & 65 & $(8) \dagger$ \\
& & 2 & 429 & $(45) \ddagger$ \\
BCG & $0.1 \mathrm{mg}$ & 13 & 78 & $(12) \ddagger$ \\
& & 7 & 84 & $(8) \ddagger$ \\
& & 2 & 198 & $(10) \dagger$ \\
PSK & $0 \cdot 1 \mathrm{mg}$ & 13 & 120 & $(16)$ \\
& & 7 & 108 & $(13)$ \\
& & 2 & 92 & $(4) \ddagger$ \\
& & & & \\
\hline
\end{tabular}

* The number of days before macrophage harvest that the agents were administered to mice.

$\dagger$ Significantly different from resident macrophages, $\mathrm{p}<0.01$. $\ddagger$ Significantly different from resident macrophages, $\mathrm{p}<0.05$.

macrophage functions and the induction of protective immunity against $L$. monocytogenes infection in mice. We have shown previously that activation of macrophages, e.g., by Lac. casei, is most readily seen in newly migrated macrophages, rather than in resident macrophages such as Kuppfer cells of the liver. ${ }^{7}$ Therefore, we used the two routes of immunisation to probe the changes which occur in newly migrating macrophages, as exemplified by the activity of peritoneal exudate cells following i.p. stimulation, and the ability to control infection in the liver.
Peritoneal macrophages harvested 13 and 7 days after i.p. injection of OK-432, BCG $(0 \cdot 1 \mathrm{mg})$ or Lac. casei showed an increase in the PMA-triggered respiratory burst, which is a correlate of macrophage activation. ${ }^{12,13,16}$ They also showed a significantly lowered APD activity, which is known to decrease in immunologically-activated macrophages but to increase in chemically-elicited macrophages. ${ }^{15}$ The listericidal activity of peritoneal macrophages induced 13 or 7 days after injection of OK-432, BCG and Lac. case $i$ was significantly increased, but was decreased in macrophages induced 2 days after injection. Thus, administration of OK-432, BCG $(0.1 \mathrm{mg})$ and Lac. casei appears to result in activation of macrophages 13 and 7 days after injection. However, neither OK432 nor BCG $(0 \cdot 1 \mathrm{mg})$ induced protection against $L$. monocytogenes infection in mice. Increased host resistance against $L$. monocytogenes 2 and 13 days after Lac. casei injection is largely mediated by macrophages newly migrating from the blood stream to the site of infection, although the increased resistance seen around 13 days after injection is also partly mediated by fixed macrophages which accumulate in the liver in response to Lac. casei treatment. ${ }^{7}$ Killing of L. monocytogenes $6 \mathrm{~h}$ after infection was not enhanced by i.v. injection of OK-432 or BCG $(0 \cdot 1 \mathrm{mg})$, but growth of the organisms between 6 and $48 \mathrm{~h}$ was inhibited, although the inhibition was lower than that caused by Lac. casei injection. In the early phase of infection (0-6 h), organisms are killed mainly by fixed macrophages in the liver, whereas during 6-48 h after infection blood monocyte-derived macrophages, newly accumulating at the site of infection, play a major role in preventing further multiplication of organisms. ${ }^{17,18}$ Thus, it appears that the functional enhancement of fixed macrophages in the liver by

Table III. The effect of immunostimulants on host resistance to L. monocytogenes

\begin{tabular}{|c|c|c|c|c|c|c|c|c|}
\hline \multicolumn{3}{|c|}{$\begin{array}{l}\text { Immunostimulant } \\
\text { administration }\end{array}$} & \multicolumn{2}{|c|}{$\begin{array}{c}\text { Protective activity } \\
\text { evident } \\
\text { (days after infection) }\end{array}$} & \multicolumn{4}{|c|}{$\begin{array}{c}\text { Viable L. monocytogenes harvested } \\
\text { from livers- mean (SEM) } \log \mathrm{cfu} / \\
\text { liver } \\
\text { (time after infection) }\end{array}$} \\
\hline \multirow{4}{*}{\begin{tabular}{l}
\multicolumn{1}{c}{ Agent } \\
None \\
BCG \\
Lac. casei
\end{tabular}} & \multirow{2}{*}{$\begin{array}{c}\text { Day* } \\
\ldots\end{array}$} & \multirow{2}{*}{$\begin{array}{l}\text { Dose } \\
\ldots\end{array}$} & \multirow{2}{*}{$\frac{3}{0 / 10}$} & \multirow{2}{*}{$\begin{array}{c}7 \\
0 / 10\end{array}$} & \multicolumn{2}{|r|}{$6 \mathrm{~h}$} & \multicolumn{2}{|c|}{$48 \mathrm{~h}$} \\
\hline & & & & & $2 \cdot 25$ & $(0.05)$ & 6.03 & $(0 \cdot 13)$ \\
\hline & 24 & $1 \mathrm{mg}$ & $10 / 10+$ & $8 / 10+$ & 0.60 & $(0 \cdot 30) \ddagger$ & 1.73 & $(0.39) \dagger$ \\
\hline & 13 & $0.1 \mathrm{mg}$ & $7 / 10 \dagger$ & $5 / 10$ & 0.96 & $(0.27) \ddagger$ & 3.90 & $(0.17) \dagger$ \\
\hline & 7 & & \multicolumn{2}{|c|}{ NT } & 1.97 & $(0.41)$ & $4 \cdot 15$ & $(0 \cdot 22)$ \\
\hline \multirow{4}{*}{ OK -432} & 2 & & $10 / 10 \dagger$ & $4 / 10$ & $2 \cdot 39$ & $(0 \cdot 15)$ & $4 \cdot 11$ & $(0 \cdot 17) \dagger$ \\
\hline & 13 & $0.1 \mathrm{mg}$ & $0 / 10$ & $0 / 10$ & $2 \cdot 35$ & $(0 \cdot 12)$ & $5 \cdot 21$ & $(0.23) \ddagger$ \\
\hline & 7 & & \multicolumn{2}{|c|}{ NT } & $2 \cdot 35$ & $(0 \cdot 12)$ & $5 \cdot 23$ & $(0.24)$ \\
\hline & 2 & & $2 / 10$ & $0 / 10$ & $2 \cdot 65$ & $(0 \cdot 15)$ & 5.08 & $(0 \cdot 28) \ddagger$ \\
\hline \multirow[t]{3}{*}{$\mathrm{BCG}$} & 13 & $0.1 \mathrm{mg}$ & $3 / 10$ & $0 / 10$ & $2 \cdot 12$ & $(0 \cdot 15)$ & $4 \cdot 51$ & $(0.46)_{+}^{\ddagger}$ \\
\hline & 7 & & \multicolumn{2}{|c|}{ NT } & $2 \cdot 30$ & $(0 \cdot 13)$ & $5 \cdot 12$ & $(0 \cdot 28) \ddagger$ \\
\hline & 2 & & $0 / 10$ & $0 / 10$ & $2 \cdot 36$ & $(0 \cdot 15)$ & 4.79 & $(0 \cdot 23) \dagger$ \\
\hline \multirow[t]{3}{*}{ PSK } & 13 & $0.1 \mathrm{mg}$ & $0 / 10$ & $0 / 10$ & $2 \cdot 28$ & $(0 \cdot 08)$ & 5.85 & $(0 \cdot 29)$ \\
\hline & 7 & & \multicolumn{2}{|c|}{ NT } & $2 \cdot 37$ & $(0 \cdot 14)$ & $5 \cdot 52$ & $(0 \cdot 37)$ \\
\hline & 2 & & $0 / 10$ & $0 / 10$ & $2 \cdot 12$ & $(0.04)$ & $5 \cdot 74$ & $(0 \cdot 20) \dagger$ \\
\hline
\end{tabular}

NT, not tested.

* The number of days before infection that the agents were administered to the mice.

+ Significantly different from resident macrophages, $\mathrm{p}<0.01$.

$\ddagger$ Significantly different from resident macrophages, $\mathrm{p}<0.05$. 
OK-432 or BCG was not accompanied by an increase in the protective activity against $L$. monocytogenes infection. Killing of L. monocytogenes during the early (up to $6 \mathrm{~h}$ ) stage of infection, as is seen with Lac. case $i,{ }^{7}$ is probably due to an increase in the number of fixed macrophages already present in the liver in response to the immunostimulating agent. Accumula-

\section{References}

1. Aoki T, Kvedar JP, Hollis VW, Bushar GS. Streptococcus pyogenes preparation $\mathrm{OK}-432$ : immunoprophylactic and immunotherapeutic effects on the incidence of spontaneous leukemia in AKR mice. J Natl Cancer Inst 1976; 56: 687690.

2. Lagrange $\mathbf{P H}$, Gheorghiu M. Antitumor activity of two BCG vaccine preparations against the Lewis lung carcinoma in mice. Cancer Immunol Immunother $1981 ; 11: 217-224$.

3. Ohno R, Imai K, Yokomaku S, Yamada K. Antitumor effect of protein bound polysaccharide preparation, PS-K, against 3 methylcholanthrene induced fibrosarcoma in C57BL/6 mice. Gann 1975; 66: 679-681

4. Saito H, Watanabe T, Tomioka H, Sato K, Kitagawa $T$. Enhanced resistance to Pseudomonas aeruginosa infection in mice pretreated with OK-432. Hiroshima J Med Sci $1983 ; 32: 235-239$.

5. Weintraub J, Weinbaum FI. The effect of BCG on experimental cutaneous leishmaniasis in mice. J Immunol 1977; 118: 2288-2290.

6. Saito H, Tomioka H, Nagashima K. Protective and therapeutic efficacy of Lactobacillus casei against experimental murine infections due to Mycobacterium fortuitum complex. J Gen Microbiol 1987; 133: 2843-2861.

7. Sato K. Enhancement of host resistance against Listeria infection by Lactobacillus casei : role of macrophages. Infect Immun $1984 ; 44: 445-451$.

8. Watanabe T, Saito H. Protection of mice against herpes simplex virus infection by a Lactobacillus casei preparation (LC 9018) in combination with inactivated viral antigen. Microbiol Immunol 1986; 30: 111-122. tion of macrophages at the site of infection 6-48 h after $L$. monocytogenes infection is important for expression of protection in mice.

Thus, the lack of protective activity seen with OK432, BCG or PSK may be due to the inability to adequately induce recruitment of macrophages to the site of infection.

9. Kato I, Kobayashi S, Yokokura T, Mutai M. Antitumor activity of Lactobacillus casei in mice. Gann $1981 ; 72: 517-523$.

10. Sato K, Saito H, Tomioka H. Enhancement of host resistance against Listeria infection by Lactobacillus casei: activation of liver macrophages and peritoneal macrophages by Lactobacillus casei. Microbiol Immunol 1988; 32: 689-698.

11. Efthymiou C, Hanson PA. An antigenic analysis of Lactobacillus acidophilus. J Infect Dis 1962; 110: 258-267.

12. Johnston RB, Godzik CA, Cohn ZA. Increased superoxide anion production by immunologically activated and chemically elicited macrophages. $J$ Exp Med 1978; 148: 115 127.

13. Tomioka $\mathbf{H}$, Saito $\mathrm{H}$. Hydrogen peroxide-releasing function of chemically elicited and immunologically activated macrophages: differential response to wheat germ lectin and concanavalin A. Infect Immun 1980; 29: 469-476.

14. Edelson PJ, Erbs C. Plasma membrane localization and metabolism of alkaline phosphodiesterase $I$ in mouse peritoneal macrophages. J Exp Med 1978; 147: 77-86.

15. Morahan PS, Edelson PJ, Gass K. Changes in macrophage ecotoenzymes associated with anti-tumor activity. $\mathrm{J} \mathrm{Im}$ munol 1980; 125: 1312-1317.

16. Nathan CF, Root RK. Hydrogen peroxide release from mouse peritoneal macrophages: dependence on sequential activation and triggering. $J$ Exp Med $1977 ; 146$; 1448-1662.

17. Mitsuyama M, Takeya K, Nomoto K, Shimotori S. Three phases of phagocyte contribution to resistance against Listeria monocytogenes. J Gen Microbiol 1978; 106: 165171.

18. Newborg MF, North RJ. On the mechanism of $\mathrm{T}$ cellindependent anti-Listeria resistance in nude mice. $J$ Immunol 1980; 124: 571-576. 